Bull. Fac. Agric., Cairo Univ., 59 (2008): 172-178.

\title{
IMPACT OF IMPROVED CROP PRODUCTION TECHNOLOGIES ON ENHANCING BARLEY AND WHEAT PRODUCTIVITY UNDER RAIN-FED AREAS OF JORDAN
}

(Received: 18.3.2008)

\author{
By \\ M. A. Bdour and A. H. Abdel-Ghani \\ Department of Plant Production, Faculty of Agriculture, Mu'tah University, \\ Al-karak. Jordan
}

\begin{abstract}
Thirty seven on-farm trials in 2001/02 and 2002/03 growing seasons were conducted to demonstrate the beneficial effects of improved crop production technologies (ICPTs) on the productivity of barley and wheat over farmers' practices in arid and semi-arid regions of Jordan. The ICPTs were compared with the farmers' method in an area of one hectare in each of the farmers' fields for each treatment (i.e. ICPTs versus farmers' practices). The results showed significant differences for grain and straw yield and an increase in harvest index, indicating the positive influence of ICPTs on the farm economic return. Compared to farmers'

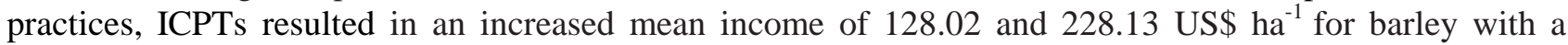
benefit-cost ratio of 1.98 and 1.79 for the application of ICPTs compared to 1.80 and 1.38 for farmers' practices in 2001/02 and 2002/03 growing seasons, respectively. Similarly, the mean income obtained from the ICPTs application in wheat was 182.27 and 133.84 US $\$ \mathrm{ha}^{-1}$ more than that resulted from farmers practices with a benefit-cost ratio of 3.25 and 2.18 for the ICPTs compared to 3.0 and 1.86 for farmers' practices in the first and second growing season, respectively. This additional income could substantially benefit small-scale farmers and improve their livelihoods in Jordan. The results from the current study indicate the potential benefits of ICPTs in enhancing barley and wheat yields, and as consequence increase net returns in the arid and semi-arid regions of Jordan.
\end{abstract}

Key words: barley, farmers' practices, grain yield, improved crop production technologies, straw, wheat.

\section{INTRODUCTION}

Barley and wheat are the principal crops of poor farmers in arid and semi-arid regions in Jordan with a very low productivity $\left(1000 \mathrm{~kg} \mathrm{ha}^{-1}\right)$. These regions represent $90 \%$ of the field crops total growing areas in Jordan (Anonymous, 2005). Barley is the predominant crop below $300 \mathrm{~mm}$ rainfall (Ceccarelli, 1987), while wheat is grown in more stable areas that receive more than $300 \mathrm{~mm}$ annual rainfall (Al-Rawashdeh and Abdel-Ghani, 2008).

Arid and semi-arid regions in Jordan are characterized by climatic variability, in terms of the amount and distribution of rainfall (Ceccarelli, 1987). Environmental stresses such as variable drought and occasional frost during the tillering stage are main causes for low productivity (Ceccarelli, 1987; Weltzien and Fischbeck, 1990). Drought is often accompanied by a relatively high temperature, which promotes evapotranspiration and hence accentuates its effects (Ceccarelli and Grando, 1991). Moreover, barley and wheat production are constrained by low soil fertility, pest problems, lack of adapted and high-yielding cultivars, un-appropriate agronomic management and low adoption of improved technology packages (Van Leur et al., 1989; Haddad et al., 2005; AlZyoud, 2007; Al-Rawashdeh and Abdel-Ghani, 2008).

The productivity of barley and wheat could possibly be increased in drought prone-areas by using high yielding varieties coupled with improved technology packages (Haddad et al., 2005; AlRawashdeh and Abdel-Ghani, 2008). There are many management decisions that farmers can make, which affect water use efficiency and reduce risk of production in water deficit conditions (Haddad et al., 2005; Al-Rawashdeh and Abdel-Ghani, 2008). However, the effectiveness of these techniques 
depends not only upon the amount, but also on the timing of precipitation and/or irrigation. In the last decade, national efforts were concentrated to increase wheat and barley productivity by adoption of improved technologies. Therefore, the objective of the current study was to present the effect of improved crop production technologies (ICPTs) in enhancing barley and wheat productivity in drought prone-areas of Jordan.

\section{MATERIALS AND METHODS}

On-farm demonstration trials (37 trials in total) were conducted in an area of one hectare during 2001/02 and 2002/03 growing seasons to demonstrate the beneficial effects of ICPTs on the productivity of barley and wheat compared to local cultivar with farmers' practices. Details of on-farm demonstration trials in terms of sample sizes in each site are presented in Table 1. The trials were conducted in seven and four selected areas in 2001/02 and 2002/03 growing seasons, respectively. Ramtha, Karak (Ghweer) and Shoubak are arid sites, characterized by low $(<300 \mathrm{~mm})$ and erratic
The ICPTs included seedbed preparation using duck foot plough, early planting (middle of November), growing improved cultivars (Rum for barley and Hourani 27 for wheat) using a seed rate of $100 \mathrm{~kg} \mathrm{ha}^{-1}$ with a mechanical seed drill that place seed at a uniform depth. Seeds were treated with Captan ( $3 \mathrm{~g} \mathrm{~kg}^{-1}$ seed) before planting. Di-Ammonium Phosphate (DAP) fertilizer was applied at a rate of $100 \mathrm{~kg} \mathrm{ha}^{-1}$ before planting plus $40 \mathrm{~kg} \mathrm{~N}$ ha $^{-1}$ top dressed at early tillering stage in the form of urea. Weeds were controlled using 2,4-D herbicide at the all locations when the plants were at the two to three leaf stage. One fungicide spray was applied at late tillering stage to control rusts and powdery mildew when necessary. On the other hand, the farmers' method included a seed bed preparation using any available plough, late planting (middle of December), no seed treatment, using of old varieties (i.e. landraces), broadcasting seeding with a higher seeding rate $\left(140 \mathrm{~kg} \mathrm{ha}^{-1}\right)$, a fertilizer dose of $100 \mathrm{~kg}$ DAP ha ${ }^{-1}$ applied as basal just before planting and no utilization of herbicides and/or manual weeding. All experiments were harvested with combined

Table (1): Details of on-farm demonstration trials in terms of sample sizes at each site.

\begin{tabular}{|c|c|c|c|c|c|}
\hline \multirow[t]{2}{*}{ Site } & \multicolumn{2}{|c|}{$\begin{array}{c}\text { Number of farmers in } \\
2001 / 2002 \text { growing season }\end{array}$} & \multicolumn{2}{|c|}{$\begin{array}{c}\text { Number of farmers in } \\
2001 / 2002 \text { growing season }\end{array}$} & \multirow[t]{2}{*}{$\begin{array}{c}\text { Total No. of } \\
\text { farmers }\end{array}$} \\
\hline & Barley & Wheat & Barley & Wheat & \\
\hline Ramtha & 3 & - & 1 & 2 & 6 \\
\hline Irbid (Maru) & - & 3 & - & - & 3 \\
\hline Maddaba (Center) & 2 & - & 2 & 3 & 7 \\
\hline Maddaba (Dieban) & 3 & 3 & - & - & 6 \\
\hline Karak (Rabba) & - & 2 & - & 2 & 4 \\
\hline Karak (Ghweer) & 2 & - & 3 & - & 5 \\
\hline Shoubak & 3 & 3 & - & - & 6 \\
\hline Total no. of farmers & 13 & 11 & 6 & 7 & 37 \\
\hline
\end{tabular}

rainfall, and have barley as the dominant field crop. Irbid, Maddaba (Center and Dieban) and Karak (Rabba) are more stable areas, semi-arid with relatively moderate to high precipitation (300-450 $\mathrm{mm}$ annually), and suitable to cultivate a wide range of crops, especially wheat, barley and some legume crops. Soil samples were collected from farmers' fields and analyzed for Nitrogen $(\mathrm{N})$ and available phosphorus $(\mathrm{P})$. The results indicate that all the soils were low in $\mathrm{N}$ (200-300 $\mathrm{mg} \mathrm{kg}^{-1}$ soil) and low to medium in available $\mathrm{P}\left(10-18 \mathrm{mg} \mathrm{kg}^{-1}\right.$ soil). The soils were alkaline $(\mathrm{pH}=7.5-8.0)$ with less than $1 \%$ organic matter and high calcium carbonate content $(15-30 \%)$. harvesters. Data were collected for the following traits: grain yield (kg ha-1), straw yield (kg ha-1) and Harvest Index (the proportion of grain to grain + straw).

In order to compare ICPTs with the farmers' practices (i.e., two treatments) in each of the farmers' fields, the paired $t$-test was used to assess whether the grain and straw yields obtained by the ICPTs and the farmers' practices are significantly different. The economic viability of ICPTs over the farmers' practices was calculated depending on prevailing prices of inputs and outputs. The return of investment using ICPTs and farmers' practices was calculated using benefit-cost ratio method (Puste and Jana, 1995; Yadav et al., 1997). 


\section{RESULTS AND DISCUSSION}

The grain and straw yield were found to be higher in 2001/02 than in 2002/03 growing seasons (Tables 2, 3, 4 and 5), which could be due to the higher amount of precipitation and the adequate distribution of rains during this season compared to 2002/03 growing season (Fig. 1). These results are in agreement with previous studies (e.g, De Ruiter and Brooking, 1993; Al-Rawashdeh and AbdelGhani, 2008), who reported that the amount and distribution of rainfall during plant development under rainfed conditions are critical for crop development and consequently, dry matter accumulation in grain and straw.
The ICPTs gave significantly higher barley grain yields in all the farmers' fields tested. Application of ICPTs resulted in a mean grain yield of 2005 and $1353 \mathrm{~kg} \mathrm{ha}^{-1}$ in 2001/02 and 2002/03 growing seasons, respectively, which are $122 \%$ and $171 \%$ higher than that obtained with farmers' practices (Tables 2 and 3). In addition to the increase in grain yield, the ICPTs also resulted in 393 and $725 \mathrm{~kg} \mathrm{ha}^{-1}$ more straw yield in barley over farmers' practices in 2001/02 and 2002/03 growing seasons, respectively. Similarly, the application of ICPTs in wheat contributed to yield increases in grain yield by $126 \%$ and $114 \%$ and in straw yield by

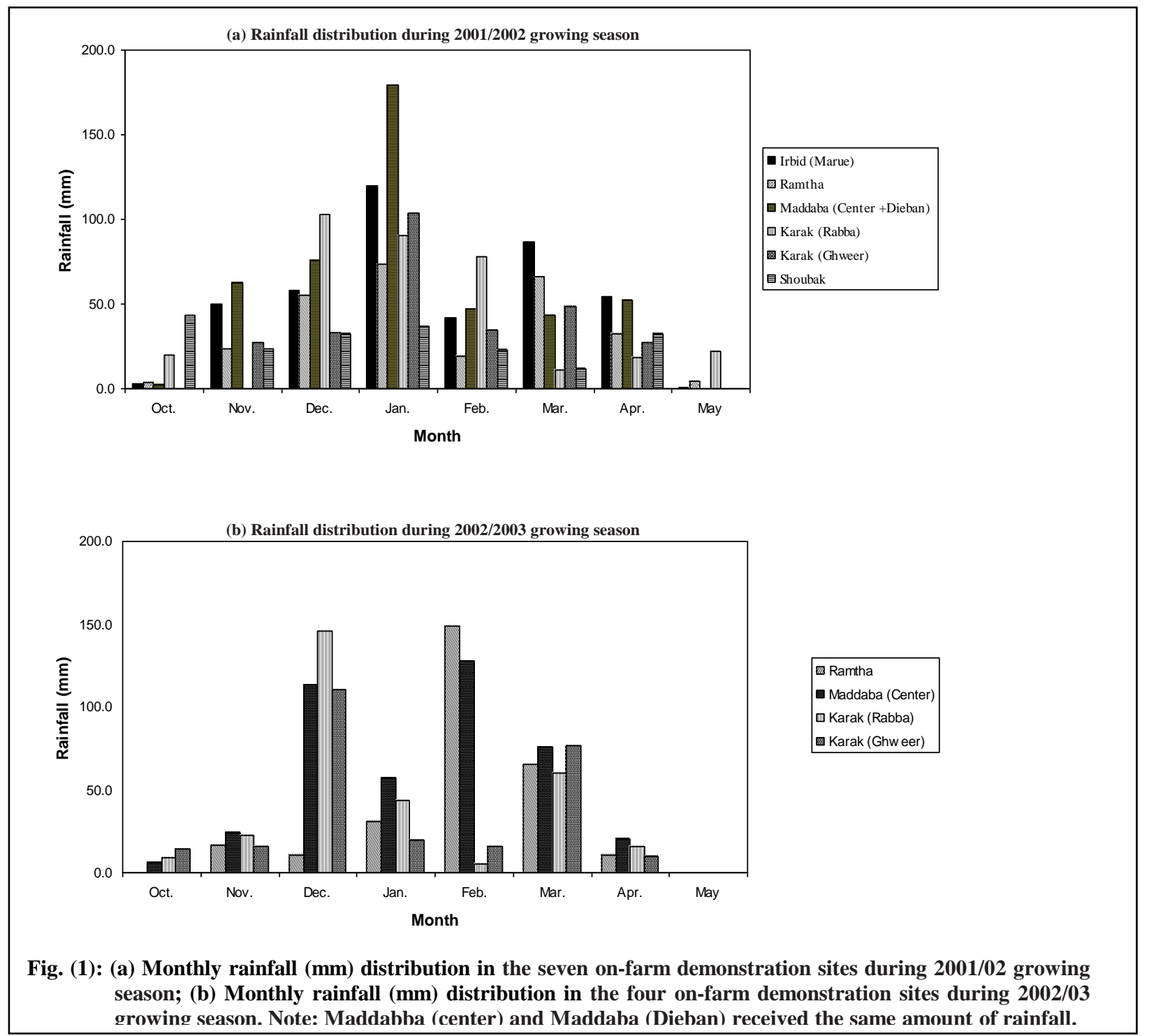


Table (2): Grain and straw yield, harvest index and economics of barley in on-farm trials (average of 13 trials) in the five on-farm demonstration sites during 2001/02 growing season.

\begin{tabular}{|c|c|c|c|c|c|c|}
\hline Cultivation method & $\begin{array}{c}\text { Grain } \\
\text { yield } \\
\left(\mathrm{kg} \mathrm{ha}^{-1}\right)\end{array}$ & $\begin{array}{l}\text { Straw yield } \\
\left(\mathrm{kg} \mathrm{ha}^{-1}\right)\end{array}$ & $\begin{array}{c}\text { Harvest } \\
\text { index }(\%)\end{array}$ & $\begin{array}{l}\text { Cost of cultivation } \\
\left(\text { US } \$ \mathbf{h a}^{-1}\right)\end{array}$ & $\begin{array}{l}\text { Net return } \\
\left(\mathrm{US} \$ \mathrm{ha}^{-1}\right)\end{array}$ & $\begin{array}{l}\text { Benefit } \\
\text { cost ratio }\end{array}$ \\
\hline $\begin{array}{l}\text { Improved crop production } \\
\text { technologies }\end{array}$ & $2005 \pm 221$ & $3081 \pm 474$ & 39.42 & 543.14 & 530.29 & 1.98 \\
\hline Farmers' practices & $1644 \pm 159$ & $2688 \pm 466$ & 37.95 & 504.92 & 402.27 & 1.80 \\
\hline Difference & $361 *$ & $393 * *$ & 1.47 & 38.22 & 128.02 & \\
\hline
\end{tabular}

$*$ and ** indicate significant $(\mathbf{P}<0.05)$ and highly significant $(\mathrm{P}<0.01)$ differences, respectively.

Table (3): Grain and straw yield, harvest index and economics of barley in on-farm trials (average of 7 trials) in the three on-farm demonstration sites during 2002/03 growing season.

\begin{tabular}{|c|c|c|c|c|c|c|}
\hline Cultivation method & $\begin{array}{c}\text { Grain yield } \\
\left(\mathrm{kg} \mathrm{ha}^{-1}\right)\end{array}$ & $\begin{array}{c}\text { Straw } \\
\text { yield } \\
\left(\mathrm{kg} \mathrm{ha}^{-1}\right)\end{array}$ & $\begin{array}{c}\text { Harvest } \\
\text { index }(\%)\end{array}$ & $\begin{array}{l}\text { Cost of } \\
\text { cultivation } \\
\left(\text { US } \$ \text { ha }^{-1}\right)\end{array}$ & $\begin{array}{l}\text { Net return } \\
\left(\text { US\$ ha }{ }^{-1}\right)\end{array}$ & $\begin{array}{c}\text { Benefit cost } \\
\text { ratio }\end{array}$ \\
\hline $\begin{array}{l}\text { Improved crop production } \\
\text { technologies }\end{array}$ & $1353 \pm 249$ & $3155 \pm 469$ & 30.01 & 505.31 & 398.87 & 1.79 \\
\hline Farmers' practices & $790 \pm 104$ & $2430 \pm 373$ & 24.53 & 455.46 & 170.74 & 1.38 \\
\hline Difference & $563 *$ & $725 * *$ & 5.48 & 49.85 & 228.13 & \\
\hline
\end{tabular}

* and ** indicate significant $(\mathbf{P}<0.05)$ and highly significant $(\mathbf{P}<0.01)$ differences, respectively.

Table (4): Grain and straw yield, harvest index and economics of wheat in on-farm trials (average of 11 trials) in the four on-farm demonstration sites during 2001/02 growing season.

\begin{tabular}{|c|c|c|c|c|c|c|}
\hline Cultivation method & $\begin{array}{c}\text { Grain yield } \\
\left(\mathrm{kg} \mathrm{ha}^{-1}\right)\end{array}$ & $\begin{array}{c}\text { Straw yield } \\
\left(\mathrm{kg} \mathrm{ha}^{-1}\right)\end{array}$ & $\begin{array}{c}\text { Harvest } \\
\text { index }(\%)\end{array}$ & $\begin{array}{l}\text { Cost of cultivatior } \\
\left.\text { (US\$ } \text { ha }^{-1}\right)\end{array}$ & $\begin{array}{l}\text { Net return } \\
(\text { US\$ ha }\end{array}$ & $\begin{array}{c}\text { Benefit } \\
\text { cost ratio }\end{array}$ \\
\hline $\begin{array}{l}\text { Improved crop } \\
\text { production technologies }\end{array}$ & $3040 \pm 321$ & $4527 \pm 303$ & 40.17 & 493.04 & 1110.36 & 3.25 \\
\hline Farmers' practices & $2411 \pm 264$ & $4317 \pm 231$ & 35.84 & 465.00 & 928.09 & 3.00 \\
\hline Difference & $629 * *$ & $210^{\mathrm{NS}}$ & 4.33 & 28.04 & 182.27 & \\
\hline
\end{tabular}

NS and ** indicate non-significant and highly significant $(\mathbf{P}<0.01)$ differences, respectively.

Table (5): Grain and straw yield, harvest index and economics of wheat in on-farm trials (average of 7 trials) in the three on-farm demonstration sites during 2002/03 growing season.

\begin{tabular}{|c|c|c|c|c|c|c|}
\hline Cultivation method & $\begin{array}{l}\text { Grain yield } \\
\left(\mathrm{kg} \mathrm{ha}^{-1}\right)\end{array}$ & $\begin{array}{l}\text { Straw yield } \\
(\mathbf{k g ~ h a - 1})\end{array}$ & $\begin{array}{c}\text { Harvest } \\
\text { Index } \\
(\%)\end{array}$ & $\begin{array}{l}\text { Cost of cultivation } \\
\left(\mathrm{US} \$ \mathrm{ha}^{-1}\right)\end{array}$ & $\begin{array}{l}\text { Net return } \\
\left(\mathrm{US} \$ \mathrm{ha}^{-1}\right)\end{array}$ & $\begin{array}{l}\text { Benefit } \\
\text { cost ratio }\end{array}$ \\
\hline $\begin{array}{l}\text { Improved crop } \\
\text { production technologies }\end{array}$ & $1241 \pm 132$ & $2700 \pm 339$ & 31.49 & 365.60 & 431.34 & 2.18 \\
\hline Farmers' practices & $1087 \pm 152$ & $2047 \pm 189$ & 34.68 & 347.35 & 297.50 & 1.68 \\
\hline Difference & $154 *$ & $653 *$ & -3.19 & 18.25 & 133.84 & \\
\hline
\end{tabular}

* indicates significant $(\mathbf{P}<0.05)$ differences.

$105 \%$ and $130 \%$ over farmer' practices in $2001 / 02$ and 2002/03 growing seasons, respectively. Moreover, high grain and straw yields in ICPTs treatments were also reflected in higher harvest index values in both seasons for barley yield trials and in 2001/02 growing season in wheat yield trials, as compared to farmers' practices treatment. The increased grain and straw yields with ICPTs were mainly due to early planting, the use of improved varieties, proper $\mathrm{N}$ application timing and rates and 
the mechanical seeding with grain drill. Date of planting usually has a large effect on seed yield of wheat and barley in West Asia and North Africa. Previous experiments showed that early planting (i.e. planting before the first rainfall of the season) results in substantial yield increase over the late planting dates (ICARDA, 1984, 1987; Ketata, 1987). Much of the early planting advantage resulted from the extended period of the growth, allowing better utilization of moister for a longer period of time, and consequently resulted in the improvement of several agronomical traits contributing to yield. Haddad et al. (2005) reported that with improved barley technology packages, crop yields increased at least two-fold; grain yield increased by $38 \%$ with improved cultivars and $51 \%$ with $\mathrm{N}$ fertilizer application. The second dosage of $\mathrm{N}$ fertilizer in form of urea, which was only applied in ICPTs treatment, probably gave substantial yield increases over that produced using farmers practices. Papakosta and Gagianas (1991) reported that $\mathrm{N}$ application in split doses increased the efficiency of $\mathrm{N}$ fertilizer use and consequently increased the mean value of grain and yield in wheat. It seems to be that weed control with 2,4-D in the ICPTs treatment has a considerable impact on weed management, which presumably reduces the competition of weeds with barley and wheat for nutrients, water, and light. According to Tanji and Regehr (1988), 2,4-D application could remove 66\% of the weeds and reduce weed dry weight by $82 \%$. Seeding with a mechanical seed drill could also result in significantly greater yields than broadcasting method because drill seeding produces a more uniform stand than broadcasting and helps in weed control (Turk and Tawaha, 2003). Similarly, studies on other crop species indicated the potential benefits of improved technology packages in enhancing kharif legumes, pearl millet, pigeonpea and sorghum yields and net returns in the dry regions (Jain et al., 1988; Ramakrishna et al., 2004; Ramakrishna et al., 2005; Reddy et al., 2007).

The economic viability of ICPTs over the farmers' practices was calculated depending on prevailing prices of inputs and outputs (Tables 2, 3, 4, and 5). Using the mechanical seed drill in ICPTs led to minimize the cultivation cost by 11.7 US\$ $\mathrm{ha}^{-1}$ in wheat and 9.5 US\$ ha ${ }^{-1}$ in barley compared to farmers' practices, since the broadcast seeding requires about $40 \%$ more seeds than drilling. The

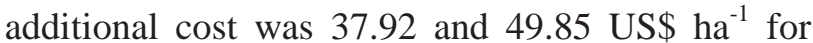
barley and 28.04 and 18.02 US $\$ \mathrm{ha}^{-1}$ for wheat in 2001/02 and 2002/03 growing seasons, respectively, (Tables 2-5) incurred due to the ICPTs as compared to farmers' practices was mainly due to additional fertilization (i.e. additional $\mathrm{N}$ application during tillering stage), seed treatment and herbicide application. However, the ICPTs resulted in an increased mean income of 128.25 and 228.13 US\$ $\mathrm{ha}^{-1}$ for barley with a cost-benefit ratio of 1.98 and 1.79 in 2001/02 and 2002/03 growing seasons, respectively (Tables 2 and 3). Similarly, using the ICPTs in wheat showed also an increased mean income of 182.27 and 133.84 US\$ ha ${ }^{-1}$ and a benefit- cost ratio of 3.25 and 2.18 for the ICPTs compared to 3.00 and 1.86 for the farmers' practices in 2001/02 and 2002/03 growing seasons, respectively (Tables 4 and 5). This additional income could substantially improve farmers' livelihoods in the dry regions of Jordan. Puste and Jana (1995) reported that the yield attributes and seed yield of pigeonpea varieties were significantly influenced by $\mathrm{P}$ fertilization with a maximum benefit-cost ratio of 4.12. In accordance, Yadav et al. (1997) indicated that with the application of $100 \%$ recommended fertilizer; sole pigeonpea gave a benefit- cost ratio of 2.94 .

In general, framers's mean income was found to be higher in 2001/02 than 2002/03 growing season, which could be due to the poor rainfall distribution in 2002/03 compared to 2001/02 growing season at the demonstration sites. Moreover, the lack of rains in 2002/03 during tillering and early flowering stage might reduce the solubility of $\mathrm{N}$, and consequently, the efficiency of $\mathrm{N}$ fertilizer use. Several reports indicated that the high inter-and intra-seasonal variation in terms of amount and distribution of rains under rain-fed conditions could limit the crops response to N (Garabet et al., 1998; Lopez-Bellido et al.,2006; AL-Rawashdeh and Abdel-Ghani,2008).

In the current study, the increased grain and straw yields with improved barley and wheat technology packages were due to selection of suitable cultivar, application of balanced nutrients at appropriate time in split doses, and carrying other cultural operations on time. The results from the study clearly bring out the potential benefits of the application of the ICPTs in enhancing wheat and barley grain and straw yields and net returns in the arid and semi-arid regions of Jordan. 


\section{REFERENCES}

Al-Rawashdeh Y.A. and Abdel-Ghani A.H. (2008). Effect of nitrogen application timing on dry matter and nitrogen assimilation and partitioning in six wheat cultivars under rain-fed conditions of Jordan. Archives of Agronomy and Soil Science 54: 149-162.

Al-Zyoud F. (2007). Investigations on certain biological and ecological parameters of the cereal leaf miner Syringopias temperatella Led. (Lepidoptera: Scythrididae). The Bulletin Faculty of Agriculture, Cairo University 58: 164-172.

Anonymous (2005). Statistics. Department of Statistics, The Hashemite Kingdom of Jordan, Amman, Jordan.

Ceccarelli S. (1987). Tolerance to climatic stress. In Proc. Fifth Intl. Barley Genet. Symp., Oct. 6-12, 1986, Okayama, Japan, p 689-702.

Ceccarelli S. and Grando S. (1991). Selection environment and environmental sensitivity in barley. Euphytica 57: 157-167.

De Ruiter J.M. and Brooking I.R. (1993). N and DM partitioning of barley grown in a dry land environment. New Zealand Journal of Crop and Horticultural Science 22: 45-55.

Garabet S., Wood M. and Ryan J. (1998). Nitrogen and water effects on wheat yield in a Mediterranean-type climate. I. Growth wateruse and nitrogen accumulation. Field Crops Research 57: 309-318.

Haddad N., Singh M. and Mamdouh Q. (2005). Onfarm evaluation of improved barley production technology packages in Jordan. Jordan Journal of Agricultural Sciences 1: 1-10.

ICARDA (1984). Cereal improvement in the dry areas: A report on the Jordan Cooperative Cereal Improvement Project, 1978/79 to 1982/83. ICARDA, Aleppo, Syria.

ICARDA. (1987). Cereals: Annual report 1986. ICARDA, Aleppo, Syria.

Jain N.K., Jain H.C. and Khandkar U.R. (1988). Response of kharif legumes to fertilizers and rhizobium inoculation. Indian Journal of Agronomy 33: 347-350.

Ketata H. (1987). Actual and Potential Yields of Cereal Crops in Moisture-Limited Environments. p. 55-62. In J.P. Srivastava et al. (ed.) Drought Tolerance in Winter Cereals. John Wiley \& Sons, Chichester, UK.
Lopez-Bellido R.J., Lopez-Bellido F.J. and LopezBellido L. (2006). Fertilizer nitrogen efficiency in durum wheat under rainfed Mediterranean conditions: effect of split application. Agronomy Journal 98: 55-62.

Papakosta D. and Gagianas A.A. (1991). N and dry matter accumulation, remobilization, and losses for Mediterranean wheat during grain filling. Agronomy Journal 83: 864-870.

Puste A. M. and Jana P.K. (1995).Effect of phosphorus and Zink on the yield attributes and yield of pigeon pea varieties grown during winter season. Madras Agricultural Journal 82: 348-351.

Ramakrishna A., Wani S.P., Rao C.S. and Reddy U.S. (2005). Effect of improved crop production technology on pigeonpea yield in resource poor rainfed areas. An Open Access Journal published by ICRISAT 1: 1-3.

Ramakrishna A., Wani S.P., Rao C.S., Reddy G.D. and Ramarao M. (2004). Economic impacts of improved pearl millet production technology in resource-poor rainfed areas of Kurnool district of Andhra Pradesh. International Sorghum and Millets Newsletter 45: 75-77.

Reddy C.R., Reddy B.V., Alur S.A., Kumar A.A. and Reddy P.S. (2007). Effect of improved crop production technologies in enhancing sorghum productivity in rainfed areas of Mahbubnagar district in Andhra Pradesh. An Open Access Journal published by ICRISAT 5: 1-2.

Tanji A. and Regehr D.L. (1988). Weeding and nitrogen effects on farmers' wheat crops in semi-arid Morocco. Weed Research 28: 101109.

Turk M. A. and Tawaha A.M. (2003). Weed control in cereals in Jordan. Crop protection 22: 239246.

Yadav R. P., Sharma R.K. and Shrivastava U.K. (1997). Fertility management in pigeon pea based intercropping system under rain fed conditions. Indian Journal of Agronomy 42: 4649.

Van Leur J.A.G., Ceccarelli S. and Grando S. (1989). Diversity for disease resistance in barley landraces from Syria and Jordan. Plant Breeding 103: 324-335.

Weltzien E. and Fischbeck G. (1990). Performance and variability of local barley landraces in neareastern environments. Plant Breeding 104: 5867. 
تأثير استخدام تقنيات إنتاج المحصول المحنة على زيادة إنتاجية الثعير والقمح تحت ظروف المناطق المطرية في الأردن

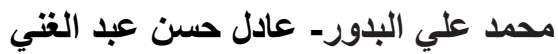

$$
\begin{aligned}
& \text { قسم الإنتاج النباتي ـ كلية الزراعة - جامعة مؤتة ـ الكرك ــ ـ الأردن }
\end{aligned}
$$

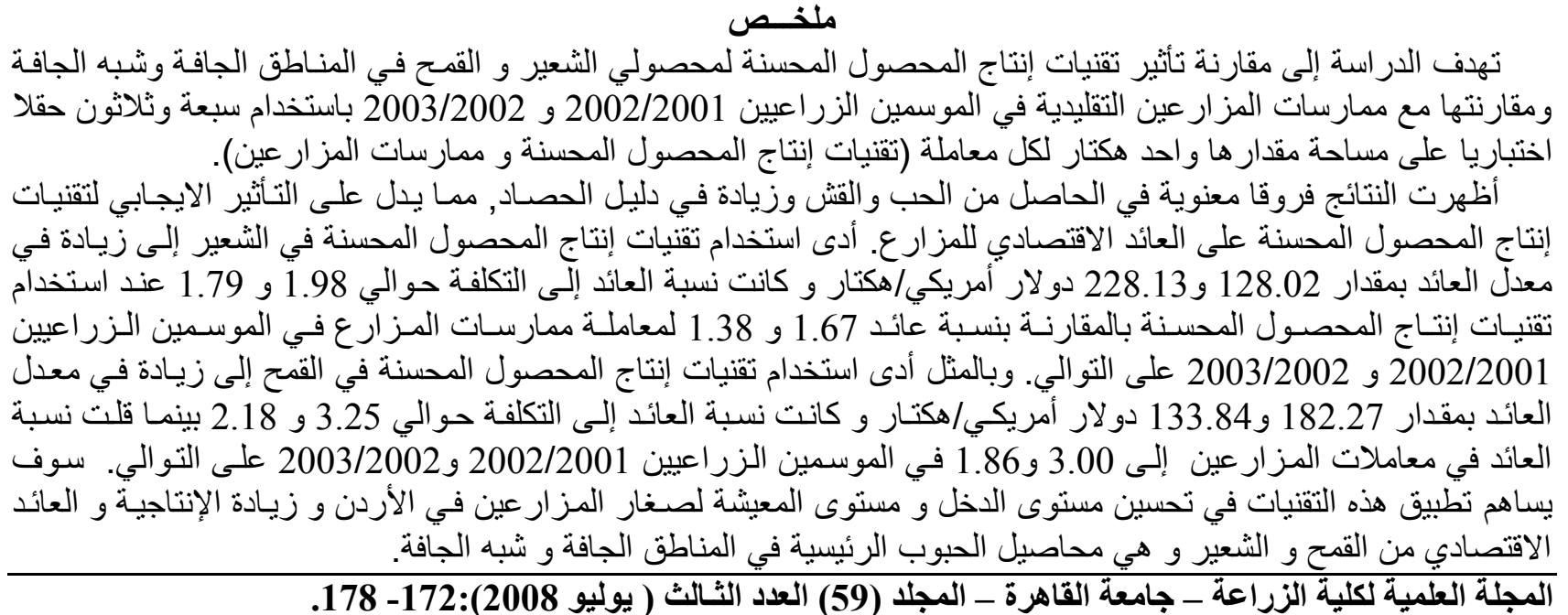

